\title{
People's Literature: \\ From Piano Pupils and Languorous Youth to Bloodsucking Adulterers and Living Buddhas
}

\section{BIRTHE ARENDRUP}

University of Copenhagen

In December 1986 student unrest surfaced in Hefei, Wuhan, Shenzhen and Kunming, eventually spreading to Shanghai, Nanjing and Beijing; contrary to earlier events of this sort, these were openly acknowledged and, until January, dealt with in a seemingly calm and moderate fashion. They appear, however, to have provoked the Party to initiate, in the second week of 1987, a series of actions aimed at curbing what some of its members felt as an intolerable, steadily growing inclination towards "bourgeois liberalization", not only among the "masses" in general, but within the Party itself. Hu Yaobang, Zhu Houze and others were removed from their posts, and Fang Lizhi, Wang Ruowang and Liu Binyan expelled from the Party; a state administration of news and publications was set up, publications were stopped and editorial committees reorganized. ${ }^{1}$ Among the most conspicuous targets of the blitz was Renmin Wenxue (People's Literature), the combined January-February issue of which was confiscated and whose chief editor, the author Liu Xinwu, was temporarily suspended from his position in order, as it was said, to give him time to make a self-examination.

Looking at this first 1987 issue ofPeople's Literature (which was available outside of China), the immediate impression is the enthusiasm and the confidence in the abilities of Chinese writers emanating from its pages. In their prefatory note, ${ }^{2}$ the editors point out reform and opening to the world as the all-important prerequisites to the current flowering of literature, the former entailing a pluralistic attitude and the latter necessitating personal and national integrity as well as a thorough understanding of the world inside and outside China. The editors express their own readiness to work wholeheartedly for the growing freedom of literature and state the considerations which led to the actual selection of stories, reportage, poems and essays: as a publication sponsored by the Chinese Writers' Association, the journal should be open to all literary schools and genres and cater to the interest of as many strata as possible of the Chinese audience. They therefore stress the variety of the themes dealt with and the differences in age, experience and style of the writers presented in the issue. Thus thematically the texts range from the depressions typical of youth to the obstacles met by people 
engaged in economic reforms, while in age and experience the authors selected vary between the extremes of $\mathrm{Lu} \mathrm{Ling}$, a prolific writer until 1954 when some of his stories "shook the literary world", and Ma Jian and others who were born only in the mid-fifties and who have thus just begun theirliterary careers. A translation of the "Editors' Note" is appended to the present paper.

Below, I shall confine myself to two of the many interesting items of the issue: the short story with which Lu Ling made his reappearance in the world of letters and the novelette about life in Tibet which was the official reason for the retaliatory measures taken against the journal.

\section{Lu Ling}

In the 1940s, Lu Ling (born 1923) was a member of a group of young writers, mostly poets, whose mentor was the poet and literary critic, Hu Feng (1905-85). His novels and stories usually dealt with people impoverished by exploitation or with intellectuals unsuccessful in attaining their idealistic aims, ${ }^{3}$ and they were generally well received, although their tragic mood did not accord with the orthodox communist literary taste. Lu Ling was not seriously criticized until 1954, when "The Battle' on the Marsh" (Wadishang de "zhanyi') was published in the March issue of People's Literature. It is one of the manyworks written at the time in response to the Party's call for descriptions in praise of the Chinese war effort in Korea and contains the romantic theme of a young Korean girl in love with a Chinese volunteer soldier. It was immediately attacked as a work glorifying subjective heroism. Two other stories by Lu Ling published that year fared no better. ${ }^{4}$ The criticism must be seen, however, as part of the much greater campaign against $\mathrm{Hu}$ Feng which had been conducted, on and off but with ever increasing intensity, for several years. When Hu Feng, the most outspoken opponent of Mao's Yan'an Talks, was arrested as a counter-revolutionary agent in July 1955, those who like Lu Ling had been loyal to him were done for as well. In view of this, his reappearance on the literary battlefield is noteworthy.

Lu Ling's new story, "Piano Pupil" (Gangqinxuesheng), ${ }^{5}$ written in August 1986, is a short piece defending intellectual ideals and values. It centres around asturdy little boy who one summer afternoon enters a bus unaccompanied by adults, to the great consternation of the female ticket seller, who feels that she will be held responsible for whatever trouble he may run into. Cross-questioning him while selling him his ticket she learns that his name is Li Guoqiang (Li Strength-of-theNation), that he is six years old and that he is on his way to a private piano lesson 
two stops ahead. He has made the trip many times before with one or the other of his parents and is quite confident that he can manage on his own.

A discussion starts among the passengers on the bus, mostly to the effect that parents nowadays neglect their children or are too ambitious on their behalf, quite often both. The boy speaks up in his parents' defence explaining that his mother, who is a worker, is on the late shift while his father has had to go on a public errand that day. Contrary to the surmise of the adults, he is not worried about travelling alone, being preoccupied with the thought of his lesson and of his piano teacher, a kind elderly lady who is stern only when talking about the magnificence of music. At the same time he is enjoying the glimpses of the trees and houses outside slowly receding as the bus makes its way through the heavy traffic. The trees along the route remind him of those in front of his teacher's small house, and to him their branches all seem to move according to the rhythm of the music he has memorized.

Asked about the address of his teacher, however, it turns out that he has chosen the wrong bus. A bespectacled young student of foreign languages, actually in a hurry to pay a visit to her ill aunt, offers to help the boy out of his dilemma by getting off the bus with him and escorting him to his teacher's place. Relieved of what might otherwise have been her burden, the ticket seller expresses her gratitude. At this point, a tall and lean young man rather aggressively observes that the ultimate aim of piano lessons is limelight and money, vanities which decent people such as he and his (heavily powdered!) girl friend don't care for. This only provokes more of the people on the bus to side openly with the boy.

The story ends with a description of the passengers smiling and waving as the student and the boy leave the bus and start walking briskly hand in hand, the student's hair streaming behind her in the wind and the barelegged boy trotting along eagerly by her side. The message of this simple, realistic and lively story is clear: intellectual pursuits make a person courageous, open-minded and ready to help. Contrary to the lanky young cynic and his dolled-up companion, such people are carried forward by their ideals and faith in life, thus providing a nation with its true strength, its hope for the future.

\section{Ma Jian}

Nobody was shocked by Lu Ling's story, of course. The work which shook the literary world this time was a novella or, more precisely, a series of five loosely 
connected, more or less imaginative descriptions of life, beliefs and customs in Tibet written by MaJian (born 1953), ${ }^{6}$ one of the young authors mentioned in the "Editors' Note" for having been born just about the time when Lu Ling was silenced. The novella, entitled "Show the Coating of YourTongue" (Liangchu nide shetai huo kongkongdangdang), ${ }^{7}$ was immediately characterized by Tang Dacheng, a representative of the cultural establishment; as a "really horrifying piece that vilifies the Tibetan people", being"full of descriptions of sex, adultery and incest". In his novella the author "just related what he had heard and dreamt up while in Tibet in a naturalistic way and with a pandering attitude ${ }^{\prime \prime} .{ }^{8}$ Obviously, it was "the inevitable result of the ideological trend of bourgeois liberalization and other erroneous ideas";:9 and obviously, again, since Chinese leaders in such matters adhere to the simplistic belief that "erroneous ideas" are fought by making them unmentionable rather than the opposite, such a novelette had to be banned.

It cannot be denied that Tang Dacheng was right in saying thatMaJian's stories deal with sex, adultery and incest, as well as in characterizing their style as naturalistic and their effect as horrifying. Even though such characterization can be considered expressive at most of a personal reaction to the stories, all readers known to this author seem to agree on this point; so far I have met or heard of no one who "liked" them.

What makes the stories so horrifying is not, however, as Tang claims, their pandering attitude. Actually, most are heart-rending chronicles of mainly, but not exclusively, sexual relations and activities, the crampedness or downright cruelty of which are fostered by isolation, poverty and superstition. The lack of doctors and midwives, of proper education and of even the most basicnecessities of life are major factors responsible for the tragedies described. While the stories may thus be said to expose some negative aspects of Chinese rule in Tibet, they definitely do not vilify the Tibetan people. On the contrary, Tibetans generally are depicted as sincere, loyal and - considering their poverty - amazingly hospitable, even to a penniless young representative of the ruling nationality such as the Chinese novelist. In line with this, he is treated with overtsarcasm, the tricks he plays on unexperienced people in order to sponge on them or make them disclose their secrets being ruthlessly reported.

A full translation of the five episodes which Ma Jian has brought together in his novella is outside the scope of this article; since the stories, however, derive much of their force from the continual accumulation of very precise details, whether beautiful, humourous, painful or macabre, the following résumé should not be expected to convey the actual feeling of the original. In two cases, I have enlarged 
my account somewhat, in an attempt to demonstrate the kinds of detail in which the text abounds. These longer sections begin and conclude my presentation.

The first episode deals with sky burial, the great attraction for tourists in Tibet, including the young Chinese vagrant photographer and novelist who is the first person narrator of the story. After several unsuccessful attempts at witnessing the rite in Lhasa, we find him travelling into the hinterland, hoping for better luck there. One late afternoon he arrives in a remote village in which a seventeen year old girl just died from loss of blood while labouring to give birth to her first child. The narrator is permitted to see her burial the next morning and to stay the night with a solitary Chinese soldier who is in charge of the telephone wires in the area.

Restless and unable to sleep, the soldier tells the girl's story: her name was Mima; at six, she had been sold to a childless couple and allowed to attend school for three years; from when she was ten, after her stepmother's death, her stepfather had slept with her, especially when he was drunk, for which reason she was despised by the other villagers; about a year ago, he had married her off to a pair of coarse brothers who had been toiling until middle-age in order to buy themselves a wife; since then, Mima was often heard screaming at night. Goaded on by the artful narrator, the soldier explains how he first met Mima when, one day a few years ago, he was making a tour of inspection on a mountain where she happened to be tending sheep. She was so lovely and guileless that he had made her a present of a long piece of wire, which she might use as clothesline, as strings for tying up parcels, etc. After that they saw each other often and she would bring him dried mutton and traditional gingke barley wine of her own making. He was too naive to make love to her, but she was the reason why he had stayed on and learned quite a bit of the language. About a year ago (actually, though unknown to him then, on the night before her wedding), she had changed their relationship into a love affair. At this point the soldier hesitates and only after some beating about the bush does he admit that Mima kept coming to his house after her marriage. He doesn't really want to tell all this and of course, if Mima's husbands should find out, the consequences might be severe; yet his desperate need to unburden his mind gets the better of him.

They set outbefore daybreak. When they reach their destination, it turns out to be just a piece of stony ground halfway up the mountains, not a nice big flat rock such as the burial ground outside Lhasa. Rusty knives, a couple of hammers and an axe with a broken handle, along with human nails, tufts of hair, fragments of bone, broken bracelets and glass beads lie scattered among the rubble. By now 
the sun has risen, its rays touching the surrounding peaks, while everything else is still shrouded in mists from a lake far below.

Out of the mist the two brothers appear carrying a big sack and various provisions and utensils for cooking. 'They are accompanied by a lama; there is no burial master, however - whether because there is no such person in the area or because the brothers cannot afford his services, the narrator does not know. He is greeted with smiles as they set to work. The sack is opened and Mima's body, all huddled up, head down and limbs tied together in front of her bosom, falls out; on her back a symbol in the form of the Buddhist swastika has been cut, the flesh along the cuts already dry and shrivelled. The brothers undo the ropes, pull her head and limbs out straight and place her lying face upward on the ground. Her eyes are still open and very bright. Then the widowers light fires for heating food and wine and for burning incense. The lama sits down close to the fires and begins to chant sutras, fingering his rosary.

The narrator keeps his distance, preparing to take photographs; adjusting the camera, he brings Mima into focus; her stomach is greatly distended because of the unborn child,-the soldier's child, perhaps, he observes. When he tries to take a picture, however, nothing happens: the shutter has stuck. This is a real blow and he has to sit down in order to steady his nerves and find out what is wrong. He works frantically for a while; when he makes a new, vain attemptattakingMima's picture he suddenly sees the corners of her mouth curl ever so faintly, not actually smiling or mocking, but moving, - definitely. He gets to his feet slowly, and at that very moment out of the blue there is a scream, followed by a gust of wind: it is a vulture, diving and circling over Mima's head before it alights on a piece of rock, folding its wings, waiting. Somewhat shaken, the narrator goes back to join the brothers; they give him zanba flour, raw dried mutton and gingke wine, which he gulps down greedily. Looking at Mima, he notices that a cotton string is hanging from her blood-stained vagina; most probably it has been used in an attempt to pull out the baby. The brothers smile at him, and the lama declares that the soul of the departed has now ascended to heaven.

The brothers turn the corpse over and the elder brother makes a long cut from the buttocks down each leg; water flows from the abdomen. The narrator takes up his camera and now, mysteriously, its functions are back to normal. The elder brother keeps cutting away big lumps of flesh, while the younger chops them into smaller pieces, alternately waving his arm to drive away the impatient vultures and flinging pieces offlesh at them. The narrator takes up a severed hand and, by way of experiment, cuts off the thumb and throws it at the birds; his fumbling makes the younger brother smile, he takes over the mutilated hand, 
places it on a stone and crushes it with a blow of the big hammer: in this way, no bones will be left lying about. By now the elder brother is almost through with his part of the job; he concludes by cutting up Mima's face from the lower jaws upwards, her bright eyes being the last to go. Taking her braids, still interlaced with red knitting wool, he staggers back to the fire. A flock of crows which up to this point have been waiting at a respectful distance now joins the vultures in a final, common fight for the mixture of flesh, brains and sacrificial qingke flour left on the ground.

The narrator looks at his watch: more than two hours have passed since he came; he will have to hurry back. The soldier promised to take him out fishing today and must be waiting for him already down by the lake.

The second episode in various ways stands out among the rest and although it is of course properly placed within the scheme of the novella, I prefer to make it the concluding part of my summary.

The third ${ }^{10}$ is a haunting, psychological study of a pitifully lonely and consciencestricken old man who has given all his property to the temple in order to atone for his sins and save his miserable daughter, unfortunately without avail. While telling the novelist of his former, incestuous relationship with his mother and of his sexual assault, after her death, on their common daughter and describing the decomposition of his fingers which his sucking during desperate periods of abstinence used to bring about, he is all the time eating blood, for lack of anything better tapped from a yak to appease the hunger of his unexpected Chinese guest, by dipping his fingers into the coagulated substance and licking them. The effect is absolutely nauseous.

The fourth is a grotesque and humorous story told by the main character himself, although the events took place four hundred years ago. In a witty and charming passage, the failing logic of this and of other details is attributed by the novelist to the effect on the human brain of life at high altitudes as well as to that, perhaps, of his limited knowledge of Tibetan. It describes the casting and erection of a sixteen meter high bell-formed and fabulously decorated bronze pagoda, the top of which was a pointed bronze pole fitting into a likewise richly carved spire of solid gold. During the many years of construction, the protagonist was apprenticed to the pagoda's creator, an elderly sculptor con engineer, by whose spirited and lovely young wife he was soon seduced, at the tender age of thirteen. Spellbound especially by her musky fragrance, he was her happy lover ever after. Upon the 
completion of the pagoda, however, while trying - against his warnings - to steal the golden spire, she had an accident, her thigh becoming transfixed on the pole over which the spire had been placed. Her crime was followed immediately by miraculous fire and rain, for hours enveloping the pagoda in clouds of hot steam and leaving her body white and shrivelled on the pole, moving with the wind like a weathercock. Only her wonderful smell and her glossy, black hair were unchanged. Unable to leave her, he stayed on until, after two years, she came loose and fluttered down slowly to the ground. He then rolled her uplike a scroll and left. Even now, after all these years, she is still with him, hanging on the wall of his dark room - right over there, look!

MaJian's stories are presented within the general framework of "root-seeking" literature. After the depressing experience of a divorce, the author has left his usual habitat to travel in Tibet, in his own unsentimental fashion searching for answers to the great and eternal questions about the meaning of life and death, love and guilt, and to recover the throbbing sensation of being alive. His work, however, ends on notes of despair and cynicism: it is true that in many ways life in Tibet is simple, free and courageous, in close contact with nature, religion and old traditions; every inch of the wilds is laden with legend and myth. Still, nature, gods and tradition are often almost unimaginably cruel and merciless masters.

The fifth and last story is so painful that the novelist's hope in writing it down is thereby to erase it from his mind. It tells of a young girl who soon after her birth was found to be a Living Buddha. She was therefore moved to the temple and brought up on Tantric wisdom and ritual, reading and memorizing holy texts and finally attending a dissecting course in order to understand the religious functions of the various organs of the human body. At fifteen, she was proficient in all these matters and at the same time awakening to the exciting fact that, unlike her lama teachers and fellow disciples, she was a woman. This was soon harshly demonstrated to her: as a Living Buddha coming of age, she must undergo the Tantric ceremony of śakti, in the text called "the irrigation by the thunderbolt"11 or simply"the male and female twin-body". Her partner in this ritual, performed in the nude to an audience of several hundred monks, was one of her lama teachers, a brother of the former Living Buddha and therefore jealous of her. Though no longer young, he was big, brutal and persevering and she ended up feeling utterly humiliated and collapsing from exhaustion.

During a following rite in which she was to be tested by being submerged in an icy river for three days, she soon perished. Upon examination, however, she was found to be indeed a true and holy Living Buddha, her bones and organs being all 
perfectly colourless and transparent. Her scull was made into a ceremonial wine cup to be used in the temple only at the "twin-body" ceremony. Much later it was sold to the author, at the greatly reduced price of one hundred yuan, by a merchant who claimed to have inherited it from his great-grandfather. Thus it is now in his possession and readers with American dollars to spend are requested to contact him; the offer, however, should be sufficiently high to enable him to reach the northeast.

Such is the grim conclusion of Ma Jian's novella. Still, in the course of his narrative, the reader has been introduced to vast and marvellous landscapes, to a people whom the common experience of hardship has made pious and openhanded, to the comforts of tents and cottages inevitably smelling of old hides and burning ox dung, and to young girls who, if the author is to be trusted, are all beautiful, with milky white skin, a milky or musky scent, and a light-hearted and lovable disposition. These positive aspects of life in Tibetare mostconspicuous in the story of the pagoda abstracted above and in the still remaining, second episode of the series.

The story now to be resumed is the only one in which the world and ways of life outside Tibet come into the picture at all and the only story, too, which the author keeps out of entirely. It is made up of third person narrative and of the inner monologues of the solitary protagonist, the only person moving in a picture which in all other respects is a still. Towards the end, several passages without punctuation are intended, presumably, to convey the protagonist's increasing difficulty in distinguishing memories, dreams, myth and reality in a totally silent world; artistically, they are convergent lines in the tight structural logic of a very beautiful story.

The episode is kept on a quiet note, the calm butinexorable authority of nature dominating the scene. It takes place near a salt water lake, Duomula, in a rugged landscape of towering peaks, deep ravines and arid slopes where only the most hardy grasses and reeds manage to hold out. It is August and even at the altitude of more than 5,000 metres the days are hot and bright.

A young Tibetan temporarily studying in Beijing has returned for the first time in several years to spend his holidays with his family. It so happens, however, that they have moved since he left, and the few people he comes across in the area hold vague and differing opinions as to their present whereabouts; he has been searching for them now for almost a month and is very upset. Five days ago he spotted the tents and herds belonging to old Zhaxiba and his large family; they had all gathered around him to hear the news of the world, but Zhaxiba, being 
hard of hearing and living largely in the past, had just asked which incantations and curses he had studied, giving him no time to answer. Instead the old man had passed on to the subject of his own experiences as a student when many years ago his father had sent him to Saga to learn imprecations powerful enough to invoke vengeance on the local Living Buddha, Danba Duojicairang, for having had one of their relatives cruelly mutilated. While serving as a lama, the man's eyes and tongue had been dug out and his hands cut off as a sacrifice to Guan Yin; hehad died only a few days later. So Zhaxiba hadleft homeandstudied diligently for a year, after which he had returned and succeeded in blinding the Living Buddha by means of the curses he had mastered.

At Zhaxiba's the student had learned that his family had set out last month to look for pasture in the vicinity of Lake Duomula. So that is where he is now, resting on a parched slope overlooking the lake. He has turned loose his black horse to feed on whatever it can find; it is restless, harassed by insects and pained by wounds from the wooden saddle after the loss of its saddle blanket a few days earlier. Since taking leave of Zhaxiba the student has met no one and for the last two days gone without food and water. The heat, thirst and hunger have drained him of his strength and made him sloppy. He dozes off, and when he comes to, the horse has disappeared. He looks for it for some time, but in vain. At dusk it suddenly turns cold and he goes to the lake, although Zhaxiba had warned him not to do so: its water is the urine of a female immortal, the Lady of Mercy, who often comes here to meet the mountain god, and whoever watches their intercourse will go blind. Yesterday he had actually happened upon a place where his family had recently camped, the traces left by their tent and fire being quite fresh; he had even recognized the tattered remains of a skirt his first younger sister, Dawamaji, used to wear. She had grown into a woman as beautiful as a ripe mountain plum, Zhaxiba had said, thereby arousing his jealousy. He lies down to sleep by the lake.

Next day he is considerably weakened, manages however to stagger to his feet and walkslowly along the shore. It is lined with white deposits of caustic soda. He tries to drink a mouthful of water from the lake, but it causes an immediate burning pain in his stomach and he has to spit it out. Real urine couldn't possibly taste as bad as this, he says to himself. Only when it grows dark once more does he stop walking. Later, after a gust of wind his home finally comes into view: his parents and two younger sisters are gathered around the fire in their tent, the women cooking and preparing buttered tea. Nothing has changed: the pot suspended over the fire, the yak hides and Dawamaji's pulu on the ground, and the leather bag for butter hanging on the central tent pole-everything is as it used 
to be. He enters and they are surprised and happy to see him. He produces the presents he has brought from Beijing - oddly enough, he thinks, hadn't the black horse run away with all these things? - advising his sisters to wash their hands before unwrapping them. His legs are numb and his back aching from the cold, so he moves closer to the fire, enjoying the smell of the burning ox dung and the taste of the buttered brick tea. Ask me something, he says and goes on to tell them about Beijing, the big dormitory building he lives in, the crowds of people in the streets, the many shops and the cinemas; they don't show much interest, don't really understand what he is talking about.

Ever since he went away he has been torn between the fascinations of life in the city and his longing for the freedom of the open spaces of his native land where gun and powder, a horse and a dog are enough to secure a carefree and leisurely life. Now half of him has come home and is listening to the rustling sound of the wind outside and to his family reporting on the breeding of their sheep and cattle. He walks about examining everything; in the cupboard front mirror the faces of Dawamaji and himself appear close together, shelooking at herself, he looking at her, her hair scratching his neck, nothing of this has changed.

If he had not been longing for this small native place of his he would not have come back. If he had not come here in search of the family tent the black horse would not have carried off the blouses, nylon stockings, table salt and orange juice extract which he had brought along for them, would it? If he took them to the outside world to see for themselves they would not want to return. Dawamaji walks over to pour fresh tea in his bowl asking, are there many girls out there? $\mathrm{He}$ explains that they wear tight-fitting jeans resembling the smooth, hairless legs of a yak and that unlike Tibetans who sleep wearing their leather gowns, they undress before going to bed. He doesn't look at her, and she doesn't look at him. When they were kids they used to sleep next to each other, but later the wanderings of his hand had startled her and made her avoid him. Since then, at the sight of girls he would always recall the wilds of Tibet and the clammy, depressing atmosphere with which they were tinged.

Now he is facing the gradually awakening swamps of Lake Duomula dejectedly. The vast sheets of caustic soda are the first to catch the light of dawn. The black horse must already have delivered his luggage at the tent, he thinks. He'll arrive on foot, then, their shepherds' dog, Pamu, rushing at him and rubbing its head against his crotch.

From its position far away behind the blue sky he watches the Gangrenbuqin Peak walking slowly towards him, surrounded by white clouds resembling the 
female immortal. He holds out for a while before falling over; a ball pen rolls out from his breast pocket and comes to a stop among the reeds.

\section{Appendix}

\section{Editors' Note: The Wings of Literature Must Move More Freely.}

Our country is speeding forward on a "two-wheeled cart". One wheel is reform, the other opening to the world. Our literature of this new age flew up from the "two-wheeled cart", and since then its wings have grown strong and vigorous through practice. Now that the wheels of time have forged ahead into 1987 our literature must flap its wings even more independently and vivaciously, advancing towards bright new horizons. This journal will devote itself wholeheartedly to the promotion of freedom for literature to move its wings!

At the beginning of the new year, we present here a combined JanuaryFebruary issue. For one thing, literature must be reformed. This implies not only that there must be authors who while they maintain their solicitude and enthusiasm for the great reforms being undertaken on the Chinese continent, affecting not only the fate of every citizen here but the fate of mankind as a whole, will supply our huge audience with realistic and stimulating masterpieces, true products of their hearts; it also implies that the present tendency towards pluralism in literature must be further developed and increasingly accepted by society, including the elaborate or casual compositions of the "small circles" which by and large may be characterized as pursuing aestheticism or "avantgarde literature", far removed from politics and economics, from society and from the major part of the readers. For a long time, the layout of this journal has indicated our keen wish for reforms, demonstrated by the incorporation of texts of diverse natures, the presentation of all sorts of flowers. Through the present combined issue, however, we also wish once again frankly and unequivocally to make known to our readers that our greatest satisfaction is derived from providing ample space for the kind of serious and mature works in whose feeling and thought the life and development of the nation are blended with personal life and development, showing the authors' courage not only to analyze society and other people but even to examine fate and self, and displaying their painstaking and untiring efforts to attain splendid new literary forms and to enhance their power to fascinate readers.

Now that literature is moving towards pluralism, the elimination of the 
despotism of feudal culture remains a problem. The way in which the "gang of four" attempted to dominate literature and art by means of their imperially. decreed "models" was long detested by everybody and is now no more than a standing joke. Everyone having a position in the world of letters, however, must still watch out for the virus of "imperial thinking" in his own blood; it is all right to stick to the group which one admires or to change one's mind constantly as to which group one agrees with; it is all right also on a basis of equality to contend with a group which one does not like or approve of; but it is inadmissible to treat groups other than one's own with the attitude and method of "not allowing other people to enjoy a good night's sleep because one's own bed is slanting". Under the principle of pluralism, everybody should abide by the rule of "in front of literature, all are equal". This journal therefore wishes to reaffirm that as a publication sponsored by the Chinese Writers' Association, it should serve all authors, whether old, middle-aged or young, professionals or amateurs, established or new; it should be open to works of all categories, styles and schools, eagerly providing a forum for the great majority of units within the complex whole; differences in assignments of work and space limitations are the sole reasons why we cannot for the time being publish popular literature, full-length novels, and works of other minor categories. As regards works representing the "small circles", if they themselves wish to give us some, we will of course publish them in order to show the rich variety already achieved within Chinese literature; it goes without saying, however, that the journal cannot be the private plot of one or a few "small circles".

The selection of items in this issue has been carefully made with a view to achieving the aims mentioned above. Mo Yan's novelette and Luo Dacheng's reportage both touch on a problem which all of society is at present highly sensitive to and concerned about, - the depressions incident to youth, to the transitional stage of being young; while Mo Yan, however, makes use of a unique literary perspective and idiom, favouring calm psychological analyses, Luo Dacheng abstracts essential data from actual life, instinctive feelings of anxiety having free scope in his text, giving rise to a variety of aesthetic impressions. Lu Ling, who thirty-three years ago in this journal shook the literary world with his stories, "The First Snow" (Chuxue) and "The Battle' on the Marsh" (Wadishang de "zhanyi"), and who later went through all kinds of hardship and suffering, is back in the journal once more, presenting a new short story; on the other hand, Yang Zhengguang, Ye Shuming and Ma Jian were born only thirty years or so ago; their highly personal writings are here solemnly brought to our readers' attention. The issue further includes a reportage closing in on frontline positions 
of the economic reforms and campaigning for the cause of reformers set on difficult treks, entitled "A Wanted Circular Issued in the Year of the Tiger" (Hunian tongjiling), beautiful and intriguinglyric poetry by Liu Zhanqiu, a series of charming literary works for children, as well as moving and thoughtprovoking prose and essays.

Secondly, literature must open itself to the world. The cry of "Heading for the world" is growing stronger with each day passing. All along, this journal has been important as a window through which observers in other parts of the world could catch glimpses of the development of Chinese literature. We are keenly aware, however, that owing to ignorance or to a wish for quick benefit and success, there have been malpractices in this respect which must be overcome. As a publication devoted to works created in Chinese, the journal must first of all address itself to people who read Chinese, i.e. to readers in China, striving as far as possibleto meet the aesthetic needs of as many strata as possible of the Chinese audience. Only on this basis are we in a position to introduce samples truly representing Chinese literature to the non-Chinese world. To produce works in Chinese aimed directly at the non-Chinese world would, in our opinion, be ludicrous. Naturally, in the great collision of Chinese and foreign culture, literature included, we must be prepared not only for happy surprises but also for disappointments as we realize the points which are common to mankind as well as the hardly eradicable divergencies between ourselves and others. In this and the following issues, we have therefore decided to strengthen the sections dealing with literary theory and criticism. The report of a conversation between Ye Junjian and Gao Xingjian, both authors familiar with the literature of Western Europe; the forceful analysis of Zhang Xinxin's creative psychology; the study of the manner in which literary editors in the West intervene in the creative work of the authors; and the opening of a new column entitled "Writers' Round Table", may perhaps be instrumental in making the steps with which we "head for the world" more stable and firm.

May the already practiced wings of our soaring literature move even more freely and vivaciously!

Birthe Arendrup is Associate Professor, East Asian Institute, University of Copenhagen 


\section{NOTES}

1 As late as in July 1987, these various initiatives were followed up by a circular issued by the State Council, calling on local authorities to enforce censure and forbidding the publication of books, journals, tapes, etc., by all except publishing units authorized by the state. See Beijing Review, 1987, No. 33, p. 4.

2 The "Editors' Note" is written under the heading, "Geng ziyou de shandong wenxue de chibang" (The wings of literature must move more freely), in Renmin Wenxue, 1987, No. 1/2, pp. 4-5.

3 His works include a novelette, "Ji'e de Guo Su'e" (The hungry Guo Su'e), a novel, Caizhu de ernümen (The children of the rich), and a collection of short stories, Qingchun de zhufu (The blessings of youth). On the life and work of Lu Ling, see for instance C.T. Hsia, A History of Modern Chinese Fiction 1917-1957 (New Haven and London: Yale University Press, 1961), pp. 329 and 634-35; C.T. Hsia, 'Residual Femininity: Women in Chinese Fiction", in Cyril Birch (ed.), Chinese Communist Literature (New York and London: Frederick A. Praeger, 1963), p. 177; and Vincent Y.C. Shih, "Enthusiast and Escapist: Writers of the Older Generation", ibid., pp. 96-98.

4 The short stories, "Nide yongyuan zhongshi de tongzhi" (Your ever faithful comrade), Jiefangiun Wenyi, February 1954, and "Zhandi de xin" (The heart of the battlefield), Renmin Wenxue, December 1954 .
5 Renmin Wenxue, 1987, No. $1 / 2$, pp. 9597.

6 Ma Jian is a former member of the Chinese Photographers' Association. In 1986 he moved to Hong Kong where he is said to support himself by painting. See Rermin Wenxue, 1987, No. 1/2, p. 116, and Zhengming, 1987, No. 3, p. 11.

7 Renmin Wenxue, 1987, No. 1/2, pp. 98116 . The title refers to a form of greeting traditionally used among the nomads; putting out one's tongue is a sign of openness, both in the sense of being receptive, lying open to the mercy of others, and in that of being frank, having nothing to hide. I owe this piece of information to the Tibetanist, Per K. Sørensen, University of Copenhagen.

8 Tang Dacheng, a member of the secretariat of the Chinese Writers' Association, in an interview with Beijing Review, 1987, No. 9, pp. 7-8.

9 In a self-criticism offered on behalf of the editorial department of Renmin Wenxue by Zhou Ming, deputy editor-in-chief of the journal, quoted in Beijing Review, 1987, no. 9, p. 7.

10 A German translation of this episode has been published recently in Drachenboot, 1987, No. 1, pp. 103-106.

11 I.e. jin'gang chu guanding, which I take to mean: the diamonid pestle pouring and butting. Jin'gang is used as a name for the ancient Indian god, Indra, and for his thunderbolt, vajra, identified with the male external generative organ. 
